\title{
SELECTION OF RHODOBACTER SPHAEROIDES P47 AS A USEFUL SOURCE OF SINGLE CELL PROTEIN
}

\author{
NAPAVARN NOPARATNARAPORN AND SHIRO NAGAI* \\ Department of Microbiology, Faculty of Science, Kasetsart University, \\ Bangkok 10900, Thailand \\ * Department of Fermentation Technology, Faculty of Engineering, Hiroshima University, \\ Higashi Hiroshima 724, Japan \\ (Received July 22, 1986)
}

\begin{abstract}
Rhodobacter sphaeroides $\mathrm{P} 47$ was selected as a potent microorganism for SCP production. The selection criteria were: high growth rate, high growth yield from consumed sugar, ability to consume various sugars, high protein content with a balanced amino acid composition, and acceptable contents of vitamin $\mathrm{B}_{12}$ and carotenoids. When the cells grew aerobically on minimal medium containing glucose, fructose and xylose as sole carbon sources, they grew at the relatively high specific growth rate of $0.12-0.161 / \mathrm{hr}$. Also, the growth yield from sugar, $0.52-0.55 \mathrm{~g}$ of cells $/ \mathrm{g}$ of sugar, was high compared with $R b$. sphaeroides $\mathrm{S}$ as a standard. In the sugar uptake test, strain P47 not only preferably consumed glucose, fructose, xylose and mannose, but also consumed maltose, sucrose, cellobiose and treharose. Strain $\mathrm{S}$ consumed only glucose, fructose, xylose and mannose. Strain P47 cells cultured on pineapple waste medium had a relatively high protein content $(66.6 \%)$ with balanced amino acid composition. The intracellular contents of vitamins $\mathrm{B}_{12}$ and $\mathrm{E}$ and carotenoids were $7.9,21$, and $80 \mathrm{mg} / 100 \mathrm{~g}$ of dry cells, respectively. These values were considerably higher than those of other photosynthetic bacteria.
\end{abstract}

To be suitable for single cell protein (SCP) production(1), microorganisms should: grow fast with efficient growth yield from carbon substrates; attain a high cell density with diverse substrate utilization; and contain balanced nutrients. Regarding potential microbial resources for SCP, several researchers (2-6) have attempted to cultivate photosynthetic bacteria on agroindustrial waste materials, eg. soybean whey, polluted water from soybean curd manufacture, swine excreta (2), wheat bran (3), soybean waste (5) and cassava starch (6). This should be feasible since the bacteria can grow on various carbon substrates under either phototrophic or heterotrophic conditions and their protein content is relatively high

Address reprints requests to: Dr. S. Nagai, Department of Fermentation Technology, Faculty of Engineering, Hiroshima University, Higashi Hiroshima 724, Japan. 
(ca. $60 \%$ ) with acceptable essential amino acids, vitamin $\mathrm{B}_{12}$, carotenoid, etc.

Another feature of photosynthetic bacteria is that they grow faster in aerobicdark conditions than in anaerobic-light conditions, and they can synthesize carotenoids even in aerobic-dark conditions (5-8). Carotenoids from photosynthetic bacteria $(2,9)$ have been supplemented in animal feedstock to intensify the color of chicken egg yolk and the skin of carp and prawn. Moreover, the production of vitamin $\mathrm{E}$, which is an essential vitamin for stock feed, was also reported (4).

In this work, we attempted to isolate photosynthetic bacteria capable of growing rapidly on diverse carbon substrates, and of accumulating higher amounts of vitamin $\mathrm{B}_{12}$ and carotenoid compared with those isolated before.

\section{MATERIALS AND METHODS}

Microorganisms. The photosynthetic bacterium Rhodobacter sphaeroides $\mathrm{S}$ ( $R b$. sphaeroides, formerly, Rhodopseudomonas sphaeroides) $(8,13)$, a potent bacterium for SCP production $(2,9)$, was used as a standard in comparing the functions of the isolates tested for SCP production.

Isolation of photosynthetic bacteria. About 150 soil and water samples collected in the Bangkok area were directly stabbed into a complex G5 agar medium (10). Cultures were incubated under illumination (ca. 3,000 lux) at $35^{\circ} \mathrm{C}$. The bacteria that developed with pink, red or brown color were inoculated into liquid G5 medium and incubated under anaerobic-light conditions at $35^{\circ} \mathrm{C}$. After growth, the bacterial cultures were streaked onto G5 agar plates and cultured under anaerobic-light conditions. Single colonies that appeared were picked up and further purified until pure single colonies were obtained. Purified cultures were stocked on G5 agar medium at $4^{\circ} \mathrm{C}$.

Selection of useful organisms. The isolated strains were inoculated into modified Lascelles medium(11), (malate-glutamate medium, $100 \mathrm{ml}$ in $250-\mathrm{ml}$ Erlenmeyer flasks) and incubated aerobically at $35^{\circ} \mathrm{C}$. After $24 \mathrm{hr}$ of cultivation, we measured the cell mass grown and the intracellular carotenoid and vitamin $B_{12}$ contents and the promising strains were selected by comparison with $R b$. sphaeroides $\mathrm{S}$.

Identification. The selected strain was identified according to the methods in Bergey's Manual of Determinative Bacteriology (12), ImHoff et al. (13), HiRAISHI et al. (14) and Kato et al.(15). Flagella were observed by means of negative staining and the intracytoplasmic membranes were analyzed with a HU-12A electron microscope (Hitachi Ltd., Tokyo) (16). To test the carbohydrate utilization of the selected strains, minimal media (6) with $0.2 \%(\mathrm{w} / \mathrm{v})$ of each carbohydrate were used. The strains were cultured under both aerobic-dark and anaerobic-light conditions $(8-10 \mathrm{klux})$ at $35^{\circ} \mathrm{C}$.

Sugar availability. The candidate strain and $R b$. sphaeroides $\mathrm{S}$ were comparatively cultured in sugar minimal medium (17) $(2 \mathrm{~g} / l$ of initial concentration) under aerobic-dark conditions (in 500-ml Sakaguchi flask with $200 \mathrm{ml}$ of medium) at $37^{\circ} \mathrm{C}$. 
During the culturing, the $\mathrm{pH}$ was kept manually in the range of 6.5-7.5.

Analysis. Cell density was measured at $660 \mathrm{~nm}$. Cell mass was based on dry weight. All the sugars were determined by high performance liquid chromatography (Model Tri Rotar V, Jasco Japan Spectroscopic Co., Ltd., Tokyo; column: Shodex Ionpak S 801; eluent: water; flow rate: $1.0 \mathrm{ml} / \mathrm{min}$ ). Total carotenoid extracted from cells was determined spectrophotometrically(18). Vitamin $\mathrm{B}_{12}$ was determined microbiologically with Escherichia coli 215 (19). Crude protein was estimated from the total nitrogen content by the Kjeldahl method (20). The amino acids of cellular protein were extracted by boiling the fresh cells in 6- $\mathrm{N} \mathrm{HCl}$ solution and analyzed with an amino acid analyzer (Model LKB Biochrom. Ltd., U.K.). Vitamins $B_{2}, B_{6}$, $\mathrm{E}$, niacin and folic acid were assayed by the method of the Association of Vitamin Chemists (21). These analyses were carried out in the Laboratory of the Department of Science Service, Ministry of Science Technology and Energy, Bangkok. The carotenoids were identified by the methods of BRITTON and GoOdwin(22), Britton (23), JENSEN and Jensen (24) and ShNeOur (25). Ubiquinone was identified by the methods of Ramasarma and Jayarama(26), Crane and Barr(27) and KROGER (28).

\section{RESULTS AND DISCUSSION}

\section{Isolation and selection of useful strains}

From ca. 150 samples of soil and water, 148 photosynthesizing bacteria were isolated. None of these bacteria grew at the expense of sulfide or thiosulfate under anaerobic-light conditions. Therefore, it is clear that all of them belong to the Family Rhodospirillaceae, the purple non-sulfur-photosynthesizing bacteria (12).

The isolated photosynthesizing bacteria were tested to select useful strains for $\mathrm{SCP}$ production. After $24 \mathrm{hr}$ of aerobic cultivation on modified Lascelles medium, 5 strains were selected on the basis of growth, intracellular contents of carotenoid and vitamin $\mathrm{B}_{12}$ compared with those of $R b$. sphaeroides $\mathrm{S}$ (Table 1). Clearly strain P47

Table 1. Purple non-sulfur photosynthetic bacteria selected for SCP production.

\begin{tabular}{|c|c|c|c|c|c|c|}
\hline & \multirow{2}{*}{$\begin{array}{l}\text { Rb. sphae- } \\
\text { roides } \mathrm{S}\end{array}$} & \multicolumn{5}{|c|}{ Isolated strain } \\
\hline & & P41 & P47 & P55 & P62 & P83 \\
\hline $\begin{array}{l}\text { Cell mass attained } \\
\qquad(\mathrm{g} \text { of cells } / l)\end{array}$ & 2.03 & 2.40 & 2.88 & 2.64 & 2.61 & 2.40 \\
\hline $\begin{array}{l}\text { Carotenoids } \\
\qquad(\mathrm{mg} / \mathrm{g} \text { of cells })\end{array}$ & 0.68 & 0.42 & 1.02 & 0.62 & 0.53 & 0.90 \\
\hline $\begin{array}{l}\text { Vitamin } \mathrm{B}_{12} \\
\qquad(\mu \mathrm{g} / \mathrm{g} \text { of cells })\end{array}$ & 44.55 & 31.15 & 68.00 & 23.77 & 24.53 & 42.45 \\
\hline
\end{tabular}


was the fastest growing and accumulated the most carotenoid and vitamin $\mathrm{B}_{12}$.

\section{Sugar utilization by strain P47}

The availability of various sugars is significant in the SCP production from agricultural wastes. Figure 1 and Table 2 show that strain P47 readily utilizes glucose, fructose, xylose and mannose and has a much higher growth rate (1.5-3 folds) than $R b$. sphaeroides S. Moreover, strain P47 utilizes the disaccharides galactose, maltose, sucrose, cellobiose and trehalose, which the standard $\mathrm{S}$ strain does not use (Table 2).

These advantageous characteristics of strain P47 make it a strong candidate for SCP production using agricultural waste materials since the waste often contains glucose, xylose, mannose, galactose and some disaccharides (29). Another important parameter in SCP production is the growth yield from the substrate, $Y_{\mathrm{x} / \mathrm{s}}, \mathrm{g}$ of cells grown per $\mathrm{g}$ of substrate consumed. Strain $\mathrm{P} 47$ gave growth yields higher than strain $\mathrm{S}$ on glucose and xylose (Table 2). It also gave higher yields than other strains on maltose, sucrose and trehalose. In addition, strain $\mathrm{P} 47$ cells contained relatively high levels of carotenoid and vitamin $\mathrm{B}_{12}$ compared to $R b$. sphaeroides $\mathrm{S}$. Among 11 sugars tested, strain P47 utilized 9 sugars (rhamnose and arabinose were not used)

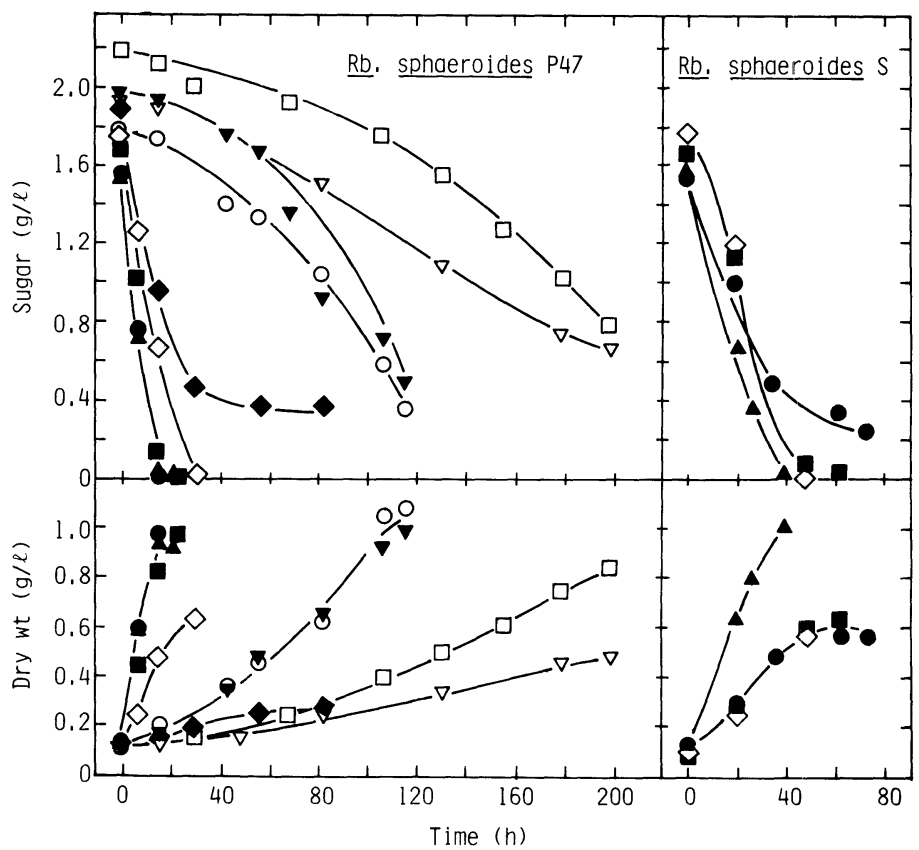

Fig. 1. Growth and sugar consumption in strain $\mathrm{P} 47$ and Rhodobacter sphaeroides $\mathrm{S}$ on sugar minimal medium under aerobic-dark conditions.

Symbols: $\bullet$, glucose; $\boldsymbol{\Lambda}$, fructose; $\mathbf{\square}$, xylose; $\diamond$, mannose; $\bullet$, galactose; $\bigcirc$, maltose; $\square$, sucrose; $\nabla$, trehalose; $\nabla$, cellobiose. 
Table 2. Growth characteristics, vitamin $\mathrm{B}_{12}$ and photopigment accumulations of strain $\mathrm{P} 47$ in contrast to $R b$. sphaeroides $\mathrm{S}$ (Data: as in Fig. 1).

\begin{tabular}{lcccc}
\hline $\begin{array}{c}\text { Sugars } \\
\text { consumed }\end{array}$ & $\begin{array}{c}\mu_{\max } \\
(1 / \mathrm{hr})\end{array}$ & $\begin{array}{c}Y_{\mathrm{x} / \mathrm{s}} \\
(\mathrm{g} \text { cell } / \mathrm{g} \text { sugar })\end{array}$ & $\begin{array}{c}\text { Car } \\
(\mathrm{mg} / \mathrm{g} \text { cell })\end{array}$ & $\begin{array}{c}\mathrm{B}_{12} \\
(\mu \mathrm{g} / \mathrm{g} \text { cell })\end{array}$ \\
\hline Strain P47 & & & & \\
$\quad$ Glucose & 0.156 & 0.54 & 0.50 & 23.80 \\
Fructose & 0.131 & 0.55 & 0.57 & 23.10 \\
Xylose & 0.116 & 0.52 & 0.76 & 24.80 \\
Mannose & 0.081 & 0.29 & 0.74 & 21.24 \\
Galactose & 0.030 & 0.12 & 0.56 & 11.85 \\
Maltose & 0.027 & 0.61 & 0.32 & 7.37 \\
Sucrose & 0.016 & 0.53 & 0.42 & 5.91 \\
Cellobiose & 0.010 & 0.29 & 0.68 & 7.27 \\
Trehalose & 0.035 & 0.58 & 0.39 & \\
Rb. sphaeroides $\mathrm{S}$ & & & & 8.62 \\
Glucose & 0.055 & 0.41 & 0.34 & 6.34 \\
Fructose & 0.105 & 0.60 & 0.26 & 6.92 \\
Xylose & 0.066 & 0.34 & 0.26 & 7.64 \\
Mannose & 0.052 & 0.26 & 0.60 & \\
\hline
\end{tabular}

$\mu_{\max }:$ maximum specific growth rate. $Y_{\mathrm{x} / \mathrm{s}}$ : growth yield from sugar consumed. Car: carotenoids; $\mathrm{B}_{12}$ : vitamin $\mathrm{B}_{12}$.

while $R b$. sphaeroides $\mathrm{S}$ used only 4 of the sugars. Thus strain P47 is a strong candidate for SCP production from agricultural wastes.

\section{Nutritional quality}

The nutritional quality of SCP is another requirement as well as the absence of toxicity (1). $R b$. sphaeroides $\mathrm{P} 47$ was cultivated on dehydrated liquid medium from pineapple peel waste (total sugar, $100 \mathrm{~g} / \mathrm{l}$ consisting of sucrose, 40; glucose, 24; fructose, 14; raffinose, 2.6, and galactose, 1.7 and others). After $60 \mathrm{hr}$ of culturing, almost all the sugars were consumed yielding $27 \mathrm{~g}$ of cells $/ l$ with a growth yield of $0.45 \mathrm{~g}$ of cells/g of sugar (30). The cells so produced were analyzed to determine the essential amino acid composition and vitamin contents (Table 3). The cell mass was acceptable in its protein content $(66.6 \%)$ and the essential amino acid compositions was comparable to other photosynthetic bacteria $(5,9,31)$. In fact, the methionine content of the photosynthetic bacteria was about 3-folds higher than that of a commercial yeast SCP(32). Strain P47 cells contained a considerable amount of vitamin $\mathrm{B}_{12}(7.89 \mathrm{mg} / 100 \mathrm{~g}$ of cells), the highest among the photosynthetic bacteria. In addition, strain P47 cells contained almost 4 times as much vitamin E $(21.01 \mathrm{mg} / 100 \mathrm{~g}$ of cells) as Rhodocyclus gelatinosus (Rc. gelatinosus, formerly Rhodopseudomonas gelatinosa $)(5,13)$. These two vitamins $\left(\mathrm{B}_{12}\right.$ and $\left.\mathrm{E}\right)$ are essential for animal feed (9). Finally, strain P47 cells contained $0.8 \mathrm{mg} / \mathrm{g}$ of cells of carotenoids, the highest among the photosynthetic bacteria. Ninet and Renaut (33) reported that the biological function of carotenoid in animal feed is to intensify the 
Table 3. Nutritional quality of strain P47 cells in comparison with those of $R b$. sphaeroides $\mathrm{S}, R b$. capsulatus, Rc. gelatinosus, and yeast from Esso-Nestle SCP.

\begin{tabular}{|c|c|c|c|c|c|}
\hline Compositions & $\begin{array}{c}\text { Strain } \\
\text { P47 }\end{array}$ & $\begin{array}{c}R b . \\
\text { sphaeroides } \mathrm{S} \\
(9)\end{array}$ & $\begin{array}{c}R b . \\
\text { capsulatus } \\
(3 I)\end{array}$ & $\begin{array}{c}R c . \\
\text { gelatinosus } \\
(5)\end{array}$ & $\begin{array}{c}\text { Esso-Nestle } \\
\text { SCP (yeast) } \\
(32)\end{array}$ \\
\hline Crude protein $(\%)$ & 66.6 & 49.6 & 66.0 & 62.0 & 50.5 \\
\hline \multicolumn{6}{|c|}{ Essential amino acid (g/100 g dry cell) } \\
\hline Lysine & 2.57 & 3.10 & 2.86 & 3.04 & 3.76 \\
\hline Histidine & 0.96 & 0.80 & 1.25 & 1.15 & 0.90 \\
\hline Threonine & 2.87 & 3.10 & 2.70 & 2.04 & 2.63 \\
\hline Valine & 2.68 & 3.42 & 3.51 & 3.44 & 3.20 \\
\hline Methionine & 1.47 & 1.43 & 1.58 & 1.92 & 0.51 \\
\hline Isoleucine & 1.78 & 2.62 & 2.64 & 2.73 & 2.63 \\
\hline Leucine & 3.90 & 4.57 & 4.50 & 5.84 & 3.54 \\
\hline Phenylalanine & 2.36 & 2.71 & 2.60 & 3.08 & 2.20 \\
\hline \multicolumn{6}{|c|}{ Vitamin $(\mathrm{mg} / 100 \mathrm{~g}$ dry cell $)$} \\
\hline Thiamine $\left(\mathrm{B}_{1}\right)$ & NA & NA & 1.20 & NA & $1.1-1.3$ \\
\hline Riboflavin $\left(B_{2}\right)$ & 1.30 & NA & 5.00 & 3.32 & $11-13$ \\
\hline Biotin & 0.63 & NA & 0.50 & 0.83 & $0.01-0.16$ \\
\hline Cobalamin $\left(\mathrm{B}_{12}\right)$ & 7.89 & 4.46 & 2.10 & 3.30 & $0.01-0.02$ \\
\hline Tocopherol (E) & 21.01 & NA & NA & 5.07 & NA \\
\hline Niacin & 0.58 & NA & 12.50 & 13.60 & $16.5-20.0$ \\
\hline Folic acid & 0.10 & NA & 6.00 & 0.72 & $0.18-0.24$ \\
\hline $\begin{array}{l}\text { Carotenoids } \\
\text { (mg/g dry cell) }\end{array}$ & 0.80 & 0.68 & NA & 0.09 & NA \\
\hline
\end{tabular}

NA, Not analyzed.

color of egg yolk, skin and fresh. It is concluded from Table 3 that the cell mass of strain P47 is highly nutrious and is well qualified as a multipurpose SCP source.

\section{Identification of the strain P47}

The identification characteristics of strain P47 are summarized in Table 4. Based on these morphological characteristics and in particular the vesicular type of intracytoplasmic membrane system (Fig. 2), the strain is assigned to the genus Rhodobacter (13). Regarding physiological characteristics, the strain could utilize acetate, tartrate, malate, lactate, succinate, glutamate, mannitol, sorbitol, glycerol, ethanol, and casamino acid as carbon substrates under heterotrophic growth and as electron donors under phototrophic growth. But propionate, benzoate, citrate, aspartate, formate, malonate, inositol, dulcitol, adonitol, and erythritol could not be utilized under either culture condition. According to these assimilative characters, the strain belongs to Rhodobacter sphaeroides (12,13,34-38). That strain P47 belongs to this species is further indicated by the characterization of the bacteriochlorophyll as type $a$, the major red carotenoid pigment under aerobic-dark condition as spheroidenone, and the red and yellow carotenoids under static-light condi- 
Table 4. Characteristics used to identify strain P47.

\begin{tabular}{|c|c|}
\hline & Characteristics \\
\hline \multicolumn{2}{|l|}{ Morphological } \\
\hline Cell form & cocci to ovoid \\
\hline \multicolumn{2}{|l|}{ Cell size $(\mu \mathrm{m})$} \\
\hline Length & $1.1-1.3$ \\
\hline Width & $0.7-0.9$ \\
\hline Cell arrangement & single or in pairs \\
\hline Gram reaction & gram negative \\
\hline Motility & motile with single polar flagellum \\
\hline Intracytoplasmic membrane system & vesicular type \\
\hline \multicolumn{2}{|l|}{ Physiological } \\
\hline Required growth factors & thiamine + biotin + nicotinic acid \\
\hline Gelatin liquefaction & negative \\
\hline Multiplication & binary fission \\
\hline Optimum temperature for growth & $35-37^{\circ} \mathrm{C}$ \\
\hline Growth & aerobic-dark, anaerobic-light \\
\hline \multicolumn{2}{|l|}{ Carbon substrates and electron donors } \\
\hline Available & $\begin{array}{l}\text { acetate, tartrate, malate, lactate, } \\
\text { succinate, glutamate, mannitol, } \\
\text { sorbitol, glycerol, ethanol, } \\
\text { casamino acid }\end{array}$ \\
\hline Not available & $\begin{array}{l}\text { benzoate, propionate, citrate, } \\
\text { aspartate, formate, malonate, } \\
\text { inositol, dulcitol, adonitol, } \\
\text { erythritol, thiosulfate, sulfide }\end{array}$ \\
\hline \multicolumn{2}{|l|}{ Photosynthetic pigments } \\
\hline Bacteriochlorophyll & type $a$ \\
\hline \multicolumn{2}{|l|}{ Carotenoids } \\
\hline Aerobic-dark & spheroidenone (red) \\
\hline Static-light & $\begin{array}{l}\text { spheroidenone (red) and } \\
\text { spheroidene (yellow) }\end{array}$ \\
\hline Ubiquinone & $\mathrm{Q}_{10}$ \\
\hline
\end{tabular}

tion as spheroidenone and spheroidene respectively. Also the ubiquinone in strain P47 was identified as $\mathrm{Q}_{10}$, the major quinone in Rhodobacter sphaeroides $(14,15$, $35)$.

The authors are indebted to Prof. K. Komagata, the University of Tokyo, for his valuable comments and discussion. We also thank Ms. Duangporn Kantachote and Ms. Rosario Nuchnoi for their technical assistance, and Ms. Rujiporn Sinchareonkul and Ms. Uraiwan Dilokkunanant for the preparation of electron micrographs.

This work was a part of the cooperative research between the JSPS and the NRCT under a Ph. D. Dissertation Program. 
a

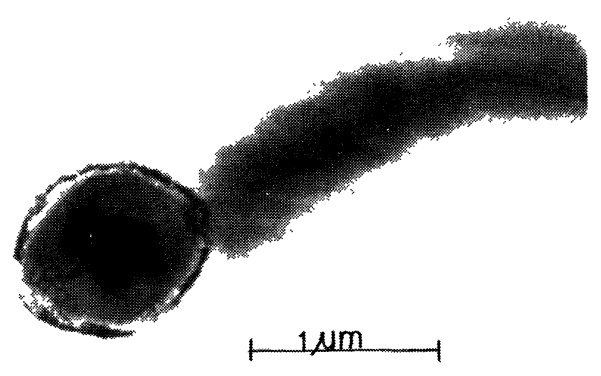

b

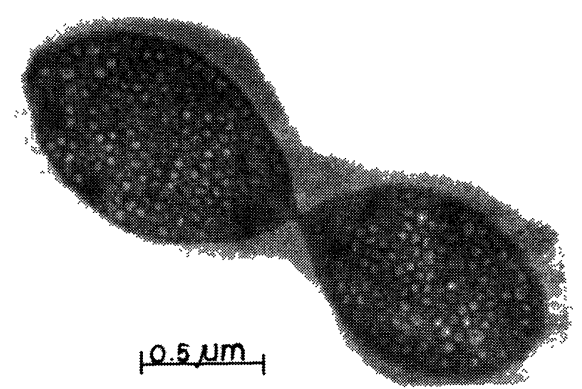

Fig. 2. Electron micrograph of strain P47.

a, polar flagellum. Bar represents $1 \mu \mathrm{m}$. b, intracytoplasmic membrane system. Bar represents $0.5 \mu \mathrm{m}$.

\section{REFERENCES}

1) I. Goldberg, In Single Cell Protein, Biotechnology Monograph, Vol. 1, ed. by S. Aiba, L. T. Fan, A. Fiechter, and K. Schugerl, Springer-Verlag, Berlin and Heidelberg (1985), p. 11.

2) H. Kitamura, Shokuhin Kogyo, 17, 44 (1974).

3) R. H. Shipman, L. T. Fan, and I. C. KaO, Adv. Appl. Microbiol., 21, 161 (1977).

4) M. Kobayashi and S. Kurata, Proc. Biochem., 13, 27 (1978).

5) K. Sasaki, N. Noparatnaraporn, M. Hayashi, Y. Nishizawa, and S. Nagai, J. Ferment. Technol., 59, 471 (1981).

6) N. Noparatnaraporn, Y. Nishizawa, M. Hayashi, and S. Nagai, J. Ferment. Technol., 61, 519 (1983).

7) K. E. Eimhjellen and S. L. Jensen, Biochim. Biophys. Acta, 82, 21 (1964).

8) Y. Nishizawa, S. Nagai, and S. Aiba, J. Ferment. Technol., 52, 526 (1974).

9) M. Kanamori, Hakko Kogyo Kaishi, 36, 934 (1978).

10) F. E. Kohlmiller, Jr. and H. Gest, J. Bacteriol., 61, 269 (1951).

11) K. Sasaki, M. Hayashi, and S. Nagai, J. Ferment. Technol., 56, 200 (1978).

12) N. Pfennig and H. G. TrüPer, In Bergey's Manual of Determinative Bacteriology, 8th ed., ed. by R. E. Buchanan and N. E. Gibbons, The Williams \& Wilkins Co., Baltimore (1974), p. 26.

13) J. F. Imhoff, H. G. Trüper, and N. Pfennig, Int. J. Syst. Bacteriol., 34, 340 (1984).

14) A. Hiraishi, Y. Hoshino, and H. Kitamura, J. Gen. Appl. Microbiol., 30, 197 (1984).

15) S. Kato, T. Urakami, and K. Komagata, J. Gen. Appl. Microbiol., 31, 381 (1985). 
16) E. S. Reynolds, J. Cell Biol., 17, 208 (1963).

17) K. Sasaki, M. L. A. E. Hurtado, Y. Nishizawa, and S. Nagai, J. Ferment. Technol., 63, 377 (1985).

18) O. Hirayama, E. A. K. Wamori, and N. Hara, Nippon Nogeikagaku Kaishi, 48, 97 (1974).

19) K. Sasaki and S. Nagai, Eur. J. Appl. Microbiol. Biotechnol., 7, 201 (1979).

20) C. A. Lang, Anal. Chem., 30, 1692 (1958).

21) M. Freed, In Methods of Vitamin Assay, 3rd ed., ed. by the Association of Vitamin Chemists, Inc. (1966), p. 389.

22) G. Britton and T. W. Goodwin, In Methods in Enzymology, Vol. 18 C, ed. by D. B. MCCormick and L. D. Wright, Academic Press, London (1971), p. 654.

23) G. Britton, In Methods in Enzymology, Vol. $111 \mathrm{~B}$, ed. by J. H. Law and H. C. Rilling, Academic Press, London (1985), p. 113.

24) S. L. Jensen and A. Jensen, In Methods in Enzymology, Vol. 23 A, ed. by A. S. Pietro, Academic Press, London (1971), p. 586.

25) E. A. Shneour, Biochim. Biophys. Acta, 62, 534 (1962).

26) T. Ramasarma and J. Jayarama, In Methods in Enzymology, Vol. 18 C, ed. by D. B. MCCormick and L. D. Wright, Acadernic Press, London (1978), p. 165.

27) F. L. Crane and R. BArr, In Methods in Enzymology, Vol. 18 C, ed. by D. B. MCCormick and L. D. Wright, Academic Press, London (1978), p. 137.

28) A. Kroger, In Methods in Enzymology, Vol. 53 D, ed. by S. Fleischer and L. Packer, Academic Press, London (1978), p. 579.

29) R. W. Detroy and C. W. Hesseltine, Proc. Biochem., 13, 2 (1978).

$30)$ N. Noparatnaraporn, W. Wongkornchawalit, D. Kantachote, and S. Nagai, J. Ferment. Technol., 64, 137 (1986).

31) H. Kitamura, Hakko Kyokaishi, 30, 76 (1972).

32) M. Kanamori, In Photosynthetic Bacteria, ed. by H. Kitamura, S. Morita, and J. Yamashita, Gakkai Shuppan Center, Tokyo (1984), p. 329.

33) L. Ninet and J. Renaut, In Microbial Technology Microbial Processes, 2nd ed., Vol. 1, ed. by H. J. Peppler and D. Perlman, Academic Press, London (1979), p. 529.

34) K. Watanabe, J. S. Kim, K. Ito, L. Buranakarl, T. Kampee, and H. Takahashi, Agric. Biol. Chem., 45, 217 (1981).

35) N. Pfennig, In The Photosynthetic Bacteria, ed. by R. K. Clayton and W. R. Sistrom, Plenum Press, New York (1978), p. 4.

36) N. B. Pellerin and H. Gest, Curr. Microbiol., 9, 339 (1983).

37) T. Satoh, Y. Hoshino, and H. Kitamura, Arch. Microbiol., 108, 265 (1976).

38) A. Jensen, O. Asamundrud, and K. E. Eimhjellen, Biochem. Biophys. Acta, 88, 466 (1964). 